\title{
Examination of the Social Behavior of 4 Age Old Preschool Children According to Teacher Views ${ }^{1}$
}

\section{Okulöncesi 4 Yaş Çocukların Sosyal Davranışlarının Öğretmen Görüşlerine Göre İncelenmesi}

\author{
Dervişe AMCA², Emine KIVANÇ ÖZTUĞ ${ }^{3}$
}

\begin{abstract}
The main aim of this research is to compare the social behavior of children according to the teacher interviews. Screening model method has been used at this research which is one of the descriptive research methods. The study group of this research was created totally 691 children, from the age group of 4 , which were observed at least 8 weeks objectively by 52 school teachers at 42 preschools in Nicosia, Kyrenia, Guzelyurt, Famagusta and Iskele which are under the Ministry of National Education of TRNC in the academic year of 2014-2015. In order to reach the demographics of the children of the study group: "Preschool Social Behaviour Questionnaire Form For Teachers" has been used to measures the children, school and family information form, relational aggression, physical aggression, prosocial behaviour and depressive feelings of age 4 group of preschool children. The data obtained through the surveys have been transmitted to the computer environment and in order to analyze the data, Statistical Package for the Social Sciences (SPSS) 20.0 for Windows Evolution version has been used. Frequency tables were used to tell the demographic characteristics on children of the research and the social behavior in preschool scale and to realize the cyclic of their behaviour. The static identifier has been given on preschool children's social behavior scale general and their scores than the average size of the subscale, standard deviation, minimum and maximum statics as identifier. According to the research findings: children with
\end{abstract}

Öz

$\mathrm{Bu}$ araștırmada, okulöncesi 4 yaş çocukların sosyal davranışlarının öğretmen görüşlerine göre incelenmesi amaçlanmıştır. Araştırmada betimsel araştırma yöntemlerinden tarama modeli kullanılmıştır. Araştırmanın çalışma grubunu; 2014-2015 eğitim-öğretim yılı KKTC'nin Nicosia, Kyrenia, Güzelyurt, Famagusta ve İskele ilçelerinde MEB'e bağlı anaokulları ile ilköğretim okullarının anasınıflarına bağlı toplam 42 okulda 52 öğretmenin, öğrencileri en az 8 hafta somut olarak gözlemlediği 4 yaş grubundaki toplam 691 çocuk oluşturmuştur. Verilerin toplanmasında, bilgilere ulaşmak amacıyla; Çocuk, Okul ve Aile Bilgi Formu, okulöncesi 4 yaş grubu çocukların ilişkisel saldırganlık, fiziksel saldırganlık, olumlu sosyal davranış ve depresif duygularını ölçmek amacı ile de "Okulöncesi Sosyal Davranış Ölçeği Öğretmen Formu" kullanılmıştır. Elde edilen veriler, bilgisayar ortamına aktarılmış ve verilerin çözümlenmesinde Statistical Package for the Social Sciences (SPSS) 20,0 for Windows Evalution versiyonu kullanılmıştır. Araştırma kapsamına alınan çocukların demografik özelliklerinin ve okulöncesi sosyal davranış ölçeğinde yer alan davranışları gerçekleştirme sıklıklarının belirlenmesinde frekans tabloları kullanılmıştır. Araştırma sonucunda; erkek çocukların, kız çocuklara göre fiziksel saldırganlık davranışı, ilişkisel saldırganlık davranışı ve depresif duyguları gösterme düzeyleri daha yüksek iken olumlu sosyal davranış düzeylerinin daha düşük olduğu saptanmıştır.

DOI: $10.18009 /$ jcer. 81338

${ }^{1}$ This section must indicate whether the article is produced form a Project, thesis or conference paper

${ }^{2}$ MA, Near East University, Pre-school Teaching, dervise91@gmail.com

${ }^{3}$ Assist. Prof., Near East Ünıversity, Music Teacher Development, ekivanc23@gmail.com 


\begin{abstract}
divorced parents compared to children with married parents have higher behavior of physical aggression, behavior of relational aggression and the show of depressive feelings besides lower levels of positive social behaviors.
\end{abstract}

Key words: Pre-School, Social Behavior, 4 Age
Anahtar kelimeler: Okulöncesi, Sosyal Davranış, 4 Yaş

\section{Introduction}

The most important and critical period of human life is pre-school period (0-6 ages). The child gains basic information, skills, attitudes and behaviours about his development in family and preschool institutions. For this reason family and preschool education center's are basic institutions for the care, development and education of the child (Ar1, 2003). The quality of education in preschool period affects the development and life of the child. It improves the child's learning and the desire for learning, and makes him a successful person in his entire life. Studies conducted in long year periods show that most of the behaviours gained at childhood years shape the personality structure, attitudes, beliefs and value judgements of the individual. From this perspective, education at preschool period is important that it affects the future life of the child (Oktay, 2003).

In preschool period, when development is fast, the child being in love and affection, his needs being met timely, his health being protected, and safety being provided are essential in that the child grows positively in terms of development and earn social behaviours. As the children going to preschool institution are in contact with their peers, they earn such behaviours as sharing, cooperation, learning by doing and experiencing, developing positive social behaviours, being individuals with high self-confidence and express themselves easily, which will affect their entire life (Özkafacı, 2012).

Social development is one of the most important processes in children's growth. It is true that this process begins right after birth and continues during the entire life of the person, but most of the behaviours form which they are affected becomes apparent especially in early childhood period (Günalp, 2007). 
Bilgisayar ve Ë̆itim

A raştırmaları Dergisi

www.joucer.com

www.dergipark.ulakbim.gov.tr/jcer
Journal of Computer and

Education Research

www.joucer.com

www.dergipark.ulakbim.gov.tr/jcer

Social development is the ability of the individual to create a successful harmony with his internal world and external world, feel joy of living, establish good relations with himself as well as other people, be accepted by others and securing successful communication (Acar, 2013).

In some studies, which examine the impact of preschool institutions on social development of children, it has been found out that children with preschool experience are more socially sufficient, self-confident, self-contained, extrovert, able to play advanced games with their peers, and analyses social relations between compared to children who did not go to preschool institutions (Eminoğlu, 2007). Social behaviours of preschool children are developed in their family, environment and preschool education institutions. The place of family is very critical in the life of the child. Behaviours of the parents are setting examples for the child, and develop positive permanent behaviours; therefore, they can affect the development of the child positively or negatively (Kılınç, 2011).

Under the light of this information, it was necessary to conduct a study on the social behaviours of preschool children. The question of what are the differentiations between social behaviours of preschool children at the age of $4 ? "$ is the basic problem of this study.

\section{Purpose}

The purpose of this study is to examine and compare the social behaviours of 4 years old preschool children according to teacher views. In line with this purpose, answers have been sought for the following questions. According to teacher opinions,

- Do social behaviours of preschool children differ based on their genders?

- Do social behaviours of preschool children differ based on the number of their siblings?

- Do social behaviours of preschool children differ based on the education status of their mothers?

- Do social behaviours of preschool children differ according to the education status of their fathers? 
Bilgisayar ve Ë̆itim

A raştırmaları Dergisi

www.joucer.com

www.dergipark.ulakbim.gov.tr/jcer
Journal of Computer and

Education Research

www.joucer.com

www.dergipark.ulakbim.gov.tr/jcer

- Is there any relation between scores obtained by preschool children from social behaviour scale sub-dimension?

\section{Method}

A descriptive quantitative research design was used in order to address the research questions in the present study. This research study was conducted with 31 pre-service and 29 in-service high school mathematics teachers from two different universities (student teachers) and five different high schools in Turkey (in-service teachers). A survey was used as an instrument to conduct this study. Three categories were defined in order to find out teachers' beliefs, views and attitudes about using digital technology, particularly calculators, during mathematics instruction: (i) teachers' beliefs and views about the cognitive effects of using calculators, (ii) teachers' experience with and use of this technology, (iii) teachers' beliefs and views about the benefits of using calculators during mathematics instruction (Fleener, 1995, p.57).

Kolmogrov-Smirnov (K-S) test was applied in order to determine the hypothesis tests which would be used in statistical analysis with the purpose of identifying whether data showed normal distribution. It was found out that the scores obtained by students from preschool social behaviour scale did not show normal distribution and non-parametric hypothesis tests were employed in the analysis. In the case that the number of independent variables is two, Mann Whitney $\mathrm{U}$ test, which is a non-parametric test, was employed in comparing independent and dependent variables; whereas Kruskal Wallis Test was used in cases where the number of independent variables was more than two. If, as a result of Kruskal Wallis Test, statistically significant difference was obtained between independent and dependent variables, Mann-Whitney $U$ test was used with the purpose of identifying the independent variable category from where the difference was originated. Spearman correlation was used in order to identify the correlation between sub-dimensions. Significance level was determined as .05. 
Bilgisayar ve Ë̆itim

A raştırmaları Dergisi

www.joucer.com

www.dergipark.ulakbim.gov.tr/jcer
Journal of Computer and

Education Research

www.joucer.com

www.dergipark.ulakbim.gov.tr/jcer

In this research scanning model, which is a descriptive research method, is used. Scanning model is a research method which aims to describe a situation in the past or present as it is. In this method, the event, individual or object that is subject to the research is tried to explain in its own conditions and as it is. The aim is to observe and determine that thing accurately without trying to change it (Karasar, 2011). The dependent variables of the research are physical aggression, relational aggression, positive social behaviour, depressive feelings. Independent variables are gender, number of siblings, the area of the school, number of children in the class, and education status of the parents.

\section{Universe sample}

The universe of this study consists of the 4 years old preschool children who are enrolled at kindergartens and nursery classes at elementary schools of Ministry of National Education in Nicosia, Kyrenia, Famagusta, Güzelyurt and Iskele districts in Turkish Republic of Northern Cyprus in 2014-2015 academic year.

Table 1. Distribution of students according to the regions

\begin{tabular}{lccc}
\hline Region & Number of students & $\mathbf{N}$ & Size of sample \\
\hline Nicosia & 448 & 35,70 & 247 \\
Kyrenia & 216 & 17,21 & 119 \\
Famagusta & 265 & 21,12 & 146 \\
Güzelyurt & 192 & 15,30 & 106 \\
İskele & 134 & 10,68 & 74 \\
\hline Total & $\mathbf{1 2 5 5}$ & $\mathbf{1 0 0 , 0 0}$ & $\mathbf{6 9 1}$ \\
\hline
\end{tabular}

In the research universe, a total of 1255 children were included, 448 of whom were in Nicosia, 216 of who were in Kyrenia, 265 of who were in Famagusta, 192 of whom were in Güzelyurt and 134 of whom were in İskele. From these 1255 students of universe, at 95\% reliability interval, and with $2.5 \%$ sampling error, interviews were held with 52 class teachers (who observed the children solidly for at least 8 weeks) of 691 children. While the research sample was being chosen, the number of 4 years old children who were enrolled at kindergartens and nursery classes of elementary schools under MEB in the districts of TRNC as of 2014-2015 academic year was obtained from Elementary Education Office of MEB and 
Bilgisayar ve Ĕgitim

Araştırmaları Dergisi

www.joucer.com

www.dergipark.ulakbim.gov.tr/jcer
Journal of Computer and

Education Research

www.joucer.com www.dergipark,ulakbim,gov.tr/jcer

layered according to density of children. From every region suitable number of sample was chosen with simple random sampling method. The distribution of the number of samples included in the sample is

In this section, findings and comments directed at sub-dimensions with the purpose of evaluating and comparing the social behaviours of preschool 4-year-old children according to teacher views are included.

Table 2. Demographic features of students

\begin{tabular}{lll}
\hline & N & $\%$ \\
\hline Gender & 345 & 49,93 \\
Girl & 346 & 50,07 \\
Boy & \\
\hline Number of siblings & 198 & 28,65 \\
No siblings & 362 & 52,39 \\
One & 88 & 12,74 \\
Two and above & \\
\hline Education status of mother & 161 & 23,30 \\
Elementary school & 336 & 48,63 \\
High school & 194 & 28,08 \\
Undergraduate / graduate & & \\
\hline Education status of father & 177 & 25,62 \\
Elementary school & 344 & 49,78 \\
High school & 170 & 24,60 \\
Undergraduate / graduate & & \\
\hline Marital status of mother & 636 & 92,04 \\
Married & 55 & 7,96 \\
Single & & \\
\hline Marital status of father & 638 & 92,33 \\
Married & 53 & $\mathbf{1 0 0 , 0 0}$ \\
Single & $\mathbf{6 9 1}$ & \\
\hline Total & & \\
\hline
\end{tabular}

When the demographic features of children are examined, it can be seen that $49,93 \%$ of the children participating at the study are girls and $50,07 \%$ of them are boys. $28,65 \%$ of the children have no siblings, $52,39 \%$ have only one sibling and $12,74 \%$ have two and more 
Bilgisayar ve Ĕgitim

Araştırmaları Dergisi

www.joucer.com

www.dergipark.ulakbim.gov.tr/jcer
Journal of Computer and

Education Research

www.joucer.com

www.dergipark.ulakbim.gov.tr/jcer

siblings. When the education status of the mothers of children participating at the research are examined, it can be seen that $23,30 \%$ are graduated from elementary school, $48,63 \%$ are graduated from high school, and $28,08 \%$ are graduated from university or post-graduate schools. $25,62 \%$ of the fathers of children are elementary school graduates, $49,78 \%$ are high school graduates and $24,60 \%$ are university / post-graduate degree holders.

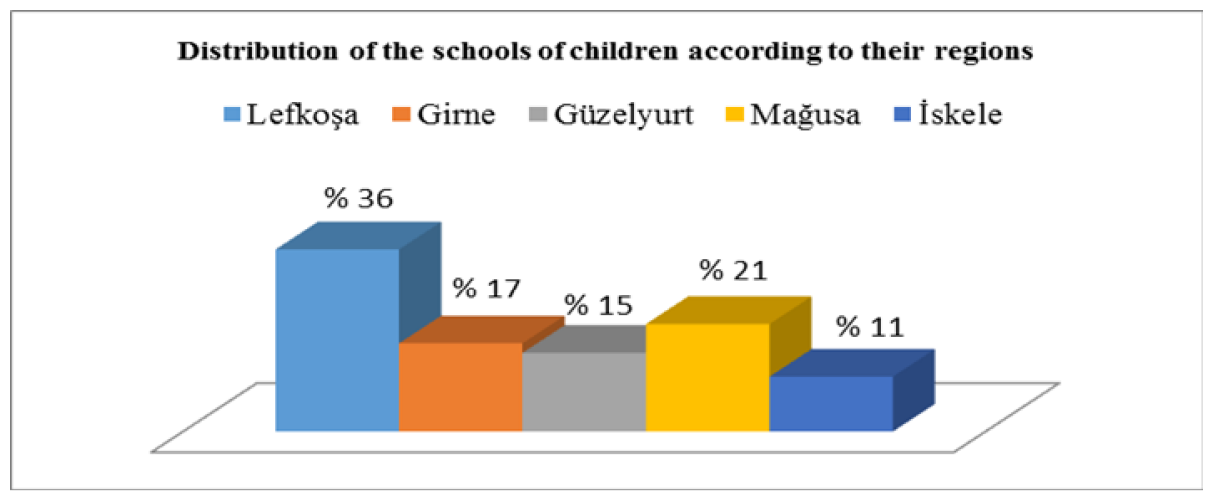

Graph 1. Distribution of the schools of children according to their regions

In the graph 1 , the distribution of children included in the research according to the regions where their schools are located can be seen. $36 \%$ of the children participating in the research were from Nicosia, 17\% were from Kyrenia, 15\% were from Güzelyurt, $21 \%$ were from Famagusta, and $11 \%$ were from İskele where they went preschool education institutions.

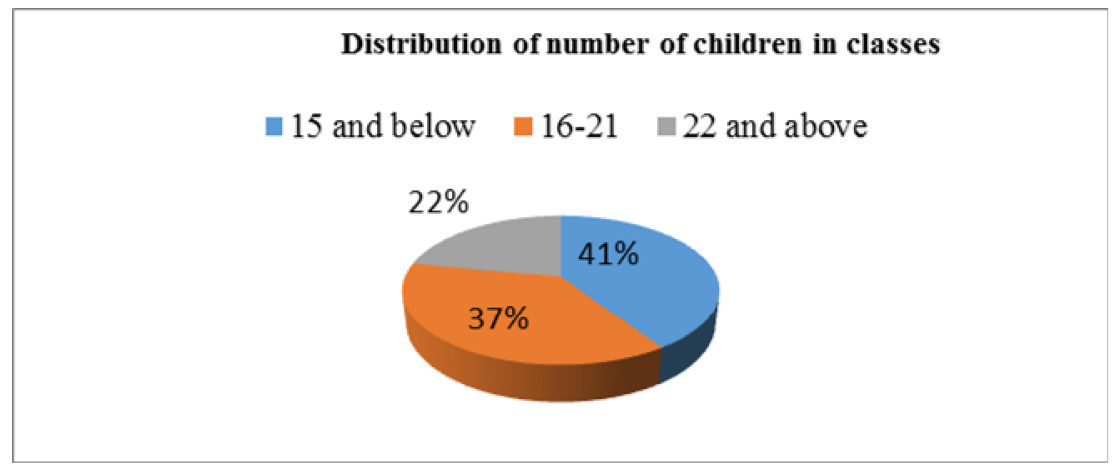

Graphic 2. Distribution of number of children in classes

In graphic 2 , it can be seen that in the classes of $41 \%$ of children there are 15 and less pupils, in the classes of $37 \%$ of children there are $16-21$ pupils and in the classes of $22 \%$ of children, there are 22 children. 
Bilgisayar ve Ĕgitim

Araştırmaları Dergisi

www.joucer.com

www.dergipark.ulakbim.gov.tr/jcer
Journal of Computer and

Education Research

www.joucer.com

www.dergipark.ulakbim.gov.tr/jcer

\section{Data collection tools}

In the research, with the purpose of reaching the demographic information of the working group of the child, child, school and family information forms were used as data collection tools, and "preschool social behaviour scale teacher form" was used in order to measure relational aggression, physical aggression, positive social behaviour and depressive emotions of preschool 4-year-old children.

Child information form: In the child information form, the purpose is to determine the level of impact on social behaviour of demographic features (gender and number of siblings) of preschool children.

School information form: in the research, the purpose of using school information form was to determine the name of the school where the child was enrolled, the region of the school, the institution to which the school is connected and the number of children in the class.

Family information form: the purpose of using this form was to determine the education and marital status of the parents of the child.

Preschool social behaviour scale teacher form: In the research, with the purpose of examining social behaviours of preschool children, the Preschool social behaviour scale teacher form (PSBS-T) which was developed by Crick et al. (1997) and adapted to Turkish by Karakuş (2008) was employed. Crick et al. (1997), from the Preschool social behaviour scale teacher form, which consisted of 25 articles in total, the six articles lower than .40 were excluded after factor analysis at the first stage. This scale consists of 19 articles aimed at identifying aggression, relational aggression, positive social behaviours and depressive feelings. The following mean scores and scale limits were used in interpreting any behaviour included in the analysis of the data. The articles in 5 Likert scale are evaluated as 1 . never (score interval 1.00-1.79), 2. rarely (score interval 1.80-2.59), 3. Occasionally (score interval: 2.60-3.39), 4. Frequently (score interval 3.40-4.19), 5. Always (score interval: 4.20-5.00). As 
Bilgisayar ve Ë̆itim

Araştırmaları Dergisi

www.joucer.com

www.dergipark.ulakbim.gov.tr/jcer
Journal of Computer and

Education Research

www.joucer.com

www.dergipark.ulakbim.gov.tr/jcer

arithmetic mean of the scores in the scale is taken, the scores of children included in the research are varying between 1, the lowest, and 5, the highest. As the score obtained from Likert type scale rises, it can be said that the child displays physical aggression, relational aggression, depressive feelings and positive social behaviour more (Karakuş, 2008).

As a result of the internal consistency test performed by the researcher, the Cronbach Alpha reliability coefficient of the scale was measured as .95 for physical aggression dimension, .94 for relational aggression sub-dimension, .93 for positive social behaviour subdimension, and .85 for depressive feelings sub-dimension. Cronbach Alpha reliability coefficient was calculated as .76 for the entire scale. Data collection tools were evaluated separately for each child by the class teacher. In this way, in a total of 42 state kindergartens and elementary school nursery classes, evaluation was made based on the observations of 52 teachers (who observe for at least 8 weeks concretely) on 691 children at the age of 4 . The questionnaire was administered after obtaining expert opinion from seven experts in field.

\section{Analysis of data}

Data obtained through the survey were transferred to computer environment and Statistical Package for the Social Sciences (SPSS) 20.0 for Windows Evolution version was used for analyzing the data. Frequency tables were used for determining the demographic features and the frequency of performing the behaviours in preschool social behaviour scale. Kolmogrov-Smirnov (K-S) test was applied in order to determine the hypothesis tests so as to find out whether the data showed normal distribution. It was found out that the scores obtained by students from preschool social behaviour scale did not show normal distribution and non-parametric hypothesis tests were used in the analysis. If the number of independent variables was two, Mann Whitney U test, which is a non-parametric hypothesis test, was used in order to compare independent variables and dependent variables, was used; when there were more than two independent variables, Kruskall Wallis test was employed. If significant difference was found between dependent and independent variables as a result of Kruskall Wallis Test, Mann Whitney U test was used in order to find out the independent 
Bilgisayar ve $\mathrm{E}_{\mathrm{ğ} \text { itim }}$

Araştrrmaları Dergisi

www.joucer.com

www.dergipark.ulakbim.gov.tr/jcer
Journal of Computer and

Education Research

www.joucer.com

www.dergipark.ulakbim.gov.tr/jcer

variable category which caused the difference. Spearmen correlation test was used in determining the relation between sub-dimensions

\section{Findings}

The data obtain as a result of this research has been presented in the following tables.

Table 3. Definitive statistics of scores obtained by children from preschool social behaviour scale

\begin{tabular}{lccccc}
\hline Sub-dimensions & n & Mean & Sd & Min & Max \\
\hline Physical aggression & 691 & 1,54 & 0,79 & 1,00 & 5,00 \\
Relational aggression & 691 & 1,59 & 0,78 & 1,00 & 5,00 \\
Positive social behaviour & 691 & 3,89 & 1,02 & 1,00 & 5,00 \\
Depressive emotions & 691 & 1,65 & 0,77 & 1,00 & 5,00 \\
\hline
\end{tabular}

The average score obtained by children from physical aggression sub-dimension is 1,54 $\pm 0,79$. Children received score between 1 (minimum) and 5 (maximum) from this subdimension. Accordingly, students never display behaviours in physical aggression subdimension according to the teacher views.

The mean score obtained by children from relational aggression sub-dimension is 1,59 $\pm 0,78$, and children received score between 1 (minimum) and 5 (maximum) from this sub-dimension. Accordingly, most of the children who participated in the research almost never display the behaviours in relational aggression dimension. The average score obtained by children from positive social behaviour sub-dimension is $3,89 \pm 1,02$ which means that children usually perform the behaviours in positive social behaviour sub-dimension frequently. The average score obtained by children participating in the research form depressive emotions sub-dimension is $1,65 \pm 0,7$. Children received score between 1 (minimum) and 5 (maximum) from this sub-dimension. Accordingly, the children included in the research generally do not display the behaviours in this sub-dimension and do not have depressive emotions. 
Bilgisayar ve $\mathrm{E}_{\mathrm{ğ} \text { itim }}$

A raştırmaları Dergisi

www.joucer.com

www.dergipark.ulakbim.gov.tr/jcer
Journal of Computer and

Education Research

www.joucer.com

www.dergipark.ulakbim.gov.tr/jcer

Table 4. Comparison of scores obtained by children from preschool social behaviour scale depending on their genders

\begin{tabular}{cccccc}
\hline Sub-dimensions & Gender & $\mathbf{n}$ & Mean & Sd & $\mathbf{p}$ \\
\hline Physical & Girl & 345 & 1,35 & 0,64 & $.00^{*}$ \\
aggression & Boy & 346 & 1,73 & 0,88 & \\
\hline Relational & Girl & 345 & 1,53 & 0,73 & $.02^{*}$ \\
aggression & Boy & 346 & 1,65 & 0,82 & \\
\hline Positive social & Girl & 345 & 4,09 & 0,99 & $.00^{*}$ \\
behaviour & Boy & 346 & 3,70 & 1,01 & \\
\hline Depressive & Girl & 345 & 1,56 & 0,70 & $.00^{*}$ \\
emotions & Boy & 346 & 1,74 & 0,82 & \\
\hline
\end{tabular}

${ }^{*} \mathrm{p}<.05$

When table 4 is examined, it is determined that the mean scores obtained from physical aggression sub-dimension by girls and boys included in the study is $1,35 \pm 0,64$ and $1,73 \pm 0,88$ respectively. It was found out that the difference in scores obtained from physical aggression sub-dimension by girls and boys was statistically significant $(p<.05)$. Boys received higher scores from girls in this sub-dimension. In other words, boys show more physical aggression compared to girls. When the scores obtained by children from relational aggression sub-dimension was examined according to their genders, it was found out that girls and boys received $1,53 \pm 0,73$ points and $1,65 \pm 0,82$ points on average respectively. It was found out that the difference in scores obtained from relational aggression sub-dimension by girls and boys was statistically significant $(\mathrm{p}<.05)$. Boys received higher scores from girls in this sub-dimension. In other words, boys show more relational aggression compared to girls. Girls and boys included in the study obtained from positive social behaviour display subdimension $4,09 \pm 0,99$ points and $3,70 \pm 1,01$ points on average respectively. It has been found out that there is statistically significant difference $(p<.05)$ between the scores obtained from positive social behaviour display sub-dimension according to the genders of children included in the research. Girls received higher scores than boys in this sub-dimension which means that positive social behaviour exposure levels of girls is higher compared to boys. It has been found out that there is statistically significant difference between scores obtained by girls and boys from depressive emotions sub-dimension $(p<.05)$. Boys received higher scores 
Bilgisayar ve $\mathrm{E}_{\mathrm{ğ} \text { itim }}$

A raştırmaları Dergisi

www.joucer.com

www.dergipark.ulakbim.gov.tr/jcer
Journal of Computer and

Education Research

www.joucer.com

www.dergipark.ulakbim.gov.tr/jcer

$(\bar{x}=1,74)$ from this sub-dimension than girls $(\bar{x}=1,56)$. In other words, the level of exposing depressive emotions is higher in boys compared to girls.

Table 5. Comparison of scores obtained from preschool social behaviour scale obtained by children according to the number of siblings

\begin{tabular}{cccccc}
\hline Sub-dimensions & $\begin{array}{c}\text { No. of } \\
\text { siblings }\end{array}$ & $\mathbf{n}$ & Mean & Sd & p \\
\hline \multirow{2}{*}{ Physical } & No siblings & 198 & 1,57 & 0,82 & .21 \\
aggression & One sibling & 362 & 1,51 & 0,78 & \\
& More than one & 131 & 1,58 & 0,79 & .21 \\
Relational & No siblings & 198 & 1,70 & 0,90 & \\
aggression & One sibling & 362 & 1,55 & 0,72 & $.00^{*}$ \\
& More than one & 131 & 1,54 & 0,73 & \\
\multirow{2}{*}{ Positive social } & No siblings & 198 & 3,77 & 1,11 & $.02^{*}$ \\
behaviour & One sibling & 362 & 4,02 & 0,96 & \\
& More than one & 131 & 3,72 & 1,02 & \\
\multirow{2}{*}{ Depressive } & No siblings & 198 & 1,77 & 0,85 & \\
emotions & One sibling & 362 & 1,57 & 0,69 & \\
& More than one & 131 & 1,72 & 0,81 & \\
\hline
\end{tabular}

${ }^{*} \mathrm{p}<.05$

When table 5 is examined, it can be seen that scores obtained by children included in the research from physical aggression and relational aggression sub-dimensions do not show significant difference depending on the number of siblings ( $p>.05)$. Children with none, one and more siblings included in the research obtained $3,77 \pm 1,11$ points, $4,02 \pm 0,96$ points and $3,72 \pm 1,02$ points on average respectively from positive social behaviour exposure subdimension. It has been found out that scores obtained by children from positive social behaviour sub-dimension showed statistically significant difference according to the number of their siblings $(\mathrm{p}<.05)$. This difference was caused by the children with one sibling, who received higher scores from positive social behaviour exposure sub-dimension compared to children with none and more than one sibling. When the scores obtained by children from depressive emotions scale depending on their number of siblings, it has been determined that children with none, one and more than one siblings received $1,77 \pm 0,85,1,57 \pm 0,69$ and $1,72 \pm 0,81$ points respectively. It has been found out that scores obtained by children from depressive emotions sub-dimension showed statistically significant difference according to 
Bilgisayar ve $\mathrm{E}_{\mathrm{ğ} \text { itim }}$

A raştırmaları Dergisi

www.joucer.com

www.dergipark.ulakbim.gov.tr/jcer
Journal of Computer and

Education Research

www.joucer.com

www.dergipark.ulakbim.gov.tr/jcer

the number of their siblings $(p<.05)$. Accordingly, this difference was caused by the children with one sibling, who received lower scores from depressive emotions sub-dimension compared to children with none and more than one sibling.

Table 6. Comparison of scores obtained from preschool social behaviour scale obtained by children according to the education status of their mothers

\begin{tabular}{cccccc}
\hline Sub-dimensions & $\begin{array}{c}\text { Education status of } \\
\text { mother }\end{array}$ & $\mathbf{n}$ & Mean & $\mathbf{s}$ & $\mathbf{p}$ \\
\hline \multirow{2}{*}{ Physical } & Elementary school & 161 & 1,64 & 0,84 & .09 \\
aggression & High school & 336 & 1,52 & 0,78 & \\
& Undergraduate / graduate & 194 & 1,49 & 0,76 & \\
\hline \multirow{2}{*}{ Relational } & Elementary school & 161 & 1,54 & 0,73 & .53 \\
aggression & High school & 336 & 1,57 & 0,75 & \\
& Undergraduate / graduate & 194 & 1,66 & 0,86 & \\
\hline \multirow{2}{*}{ Positive social } & Elementary school & 161 & 3,73 & 1,03 & $.04^{*}$ \\
behaviour & High school & 336 & 3,95 & 1,01 & \\
& Undergraduate / graduate & 194 & 3,94 & 1,02 & \\
\hline \multirow{2}{*}{ Depressive } & Elementary school & 161 & 1,73 & 0,86 & .51 \\
emotions & High school & 336 & 1,62 & 0,75 & \\
& Undergraduate / graduate & 194 & 1,65 & 0,71 & \\
\hline
\end{tabular}

${ }^{*} \mathrm{p}<.05$

In Table 6, the comparison of scores obtained by children covered by the research according to education status of their mothers is provided. When table 4.5 is examined it has been found out that scores obtained by children included in the research from physical aggression, relational aggression and depressive emotions sub-dimensions do not show significant difference depending on the education status of their mothers ( $p>.05)$. Studied children with mothers graduated from elementary school obtained $3,73 \pm 1,03$ points on average from positive social behaviour exposure sub-dimension, children with mothers graduated from high school obtained 3,95 $\pm 1,01$ points and children with mothers graduated from university or higher schools obtained $3,94 \pm 1,02$ points on average. It has been found out that there is statistically significant difference between scores obtained from positive social behaviour exposure sub-dimension depending on the education status of mothers included in the study $(\mathrm{p}<.05)$. This difference is caused by the students whose mothers are elementary school graduates, who received lower scores from positive social behaviour sub-dimension 
Bilgisayar ve $\mathrm{E}_{\mathrm{ğ} \text { itim }}$

A raştırmaları Dergisi

www.joucer.com

www.dergipark.ulakbim.gov.tr/jcer
Journal of Computer and

Education Research

www.joucer.com

www.dergipark,ulakbim.gov.tr/jcer

compared to students whose mothers are high school, university or higher school graduates. Accordingly, it can be claimed that as the education status (level) of parents lower, relational aggressive behaviours of their children decrease, based on the views of teachers who constitute the sample.

Table 7. Comparison of scores obtained from preschool social behaviour scale obtained by children according to the education status of their fathers

\begin{tabular}{cccccc}
\hline \multirow{2}{*}{ Sub-dimensions } & Education status of father & $\mathrm{n}$ & Mean & $\mathrm{Sd}$ & $\mathrm{p}$ \\
& & & & & \\
& & & \\
& Elementary school & 177 & 1,61 & 0,83 & $.03^{*}$ \\
Physical & High school & 344 & 1,57 & 0,82 & \\
aggression & Undergraduate / graduate & 170 & 1,41 & 0,69 & \\
& Elementary school & 177 & 1,53 & 0,71 & .54 \\
Relational & High school & 344 & 1,62 & 0,80 & \\
aggression & Undergraduate / graduate & 170 & 1,58 & 0,81 & \\
& Elementary school & 177 & 3,80 & 1,05 & .23 \\
Positive social & High school & 344 & 3,90 & 1,01 & \\
behaviour & Undergraduate / graduate & 170 & 3,98 & 1,02 & \\
& Elementary school & 177 & 1,68 & 0,85 & .34 \\
Depressive & High school & 344 & 1,62 & 0,76 & \\
emotions & Undergraduate / graduate & 170 & 1,68 & 0,69 & \\
\hline${ }^{*} \mathrm{p}<.05$ & & & &
\end{tabular}

When table 7 is examined, it has been found out that scores obtained by children included in the research from relational aggression, positive social behaviour exposure and depressive emotions sub-dimensions do not show significant difference depending on the education status of their fathers ( $p>05)$. Studied children with fathers graduated from elementary school obtained $1,61 \pm 0,83$ points on average from physical aggression subdimension, children with mothers graduated from high school obtained 1,57 $\pm 0,82$ points and children with mothers graduated from university or higher schools obtained $1,41 \pm 0,69$ points on average. It has been found out that there is statistically significant difference between scores obtained from physical aggression sub-dimension depending on the education status of fathers included in the study $(\mathrm{p}<.05)$. This difference is caused by the students whose fathers are university or higher school graduates, who received lower scores from physical 
Bilgisayar ve $\mathrm{E}_{\mathrm{ğ} \text { itim }}$

A raştırmaları Dergisi

www.joucer.com

www.dergipark.ulakbim.gov.tr/jeer
Journal of Computer and

Education Research

www.joucer.com

www.dergipark.ulakbim.gov.tr/jcer

aggression sub-dimension compared to students whose mothers are elementary or high school graduates.

Table 8. Comparison of scores obtained from preschool social behaviour scale obtained by children according to regions of the schools Mann Whitney $U$ test.

\begin{tabular}{lccccc}
\hline Sub-dimensions & Regions & $\mathbf{n}$ & Mean & Sd & p \\
\hline \multirow{3}{*}{ Physical } & Nicosia & 247 & 1,52 & 0,75 & .44 \\
aggression & Kyrenia & 119 & 1,63 & 0,89 & \\
& Güzelyurt & 106 & 1,66 & 0,88 & \\
& Famagusta & 145 & 1,47 & 0,77 & \\
& İskele & 74 & 1,40 & 0,62 & \\
Relational & Nicosia & 247 & 1,56 & 0,71 & $.04^{*}$ \\
aggression & Kyrenia & 119 & 1,76 & 0,91 & \\
& Güzelyurt & 106 & 1,67 & 0,84 & \\
& Famagusta & 145 & 1,50 & 0,80 & \\
& İskele & 74 & 1,47 & 0,61 & \\
Positive social & Nicosia & 247 & 3,77 & 1,01 & $.02^{*}$ \\
behaviour & Kyrenia & 119 & 4,09 & 1,04 & \\
& Güzelyurt & 106 & 3,89 & 0,95 & \\
& Famagusta & 145 & 3,92 & 1,10 & \\
\hline \multirow{2}{*}{ Depressive } & İskele & 74 & 3,93 & 0,91 & \\
emotions & Nicosia & 247 & 1,71 & 0,77 & $.00^{*}$ \\
& Kyrenia & 119 & 1,41 & 0,53 & \\
& Güzelyurt & 106 & 1,72 & 0,74 & \\
\hline & Famagusta & 145 & 1,65 & 0,91 & \\
\hline
\end{tabular}

${ }^{*} \mathrm{p}<.05$

When table 8 is examined it has been found out that there was no statistically significant difference between scores obtained from physical aggression sub-dimension by children included in the research ( $p>.05)$. When the scores obtained by children from relational aggression sub-dimension according to the regions of schools, it has been found out that children going to schools in Nicosia, Kyrenia, Güzelyurt, Famagustaand İskele regions received $1,56 \pm 0,71$ points, $1,76 \pm 0,91$ points, $1,67 \pm 0,84$ points, $1,50 \pm 0,80$ points and $1,47 \pm 0,61$ points on average respectively. It has been found out that there was statistically significant difference between scores obtained from relational aggression sub-dimension according to the regions of schools $(\mathrm{p}<.05)$. Children enrolled at schools in Kyrenia and Güzelyurt regions received higher scores form this sub-dimension compared to children 
Bilgisayar ve $\mathrm{E}_{\mathrm{ğ} \text { itim }}$

Araştırmaları Dergisi

www.joucer.com

www.dergipark.ulakbim.gov.tr/jcer
Journal of Computer and

Education Research

www.joucer.com

www.dergipark.ulakbim.gov.tr/jcer

going to schools in other regions. Within the research, children going to schools in Nicosia,

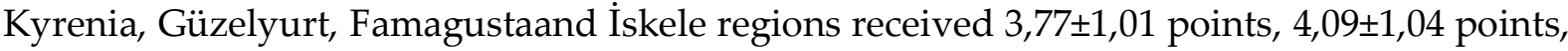
$3,89 \pm 0,95$ points, $3,92 \pm 1,10$ points and $3,93 \pm 0,91$ points on average respectively from positive social behaviour sub-dimension. It has been found out that there was statistically significant difference between scores obtained from positive social behaviour sub-dimension according to the regions of schools $(\mathrm{p}<.05)$. Children going to schools in Nicosia region received lower points form this sub-dimension compared to children going to schools in other regions. It has been found out that there was statistically significant difference between scores obtained from depressive emotion sub-dimension according to the regions of schools $(\mathrm{p}<.05)$. Average points obtained from depressive emotions sub-dimensions by children going to schools in Kyreniaregion $(\bar{x}=1,41)$ are lower than the scores of children going to schools in other regions.

Table 9. Comparison of scores obtained from preschool social behaviour scale obtained by children according to number of pupils in class Mann Whitney $U$ test

\begin{tabular}{cccccc}
\hline Sub-dimensions & Number of pupils & $\mathrm{n}$ & Mean & $\mathrm{Sd}$ & $\mathrm{p}$ \\
\hline Physical & 15 children and less & 282 & 1,52 & 0,72 & .24 \\
aggression & 16-21 children & 257 & 1,57 & 0,82 & \\
& 22 children and above & 152 & 1,50 & 0,86 & \\
\hline \multirow{2}{*}{ Relational } & 15 children and less & 282 & 1,54 & 0,70 & $.00^{*}$ \\
aggression & $16-21$ children & 257 & 1,69 & 0,83 & \\
& 22 children and above & 152 & 1,51 & 0,82 & \\
\hline \multirow{2}{*}{ Positive social } & 15 children and less & 282 & 3,89 & 1,01 & $.03^{*}$ \\
behaviour & $16-21$ children & 257 & 3,81 & 1,02 & \\
& 22 children and above & 152 & 4,04 & 1,04 & \\
\hline \multirow{2}{*}{ Depressive } & 15 children and less & 282 & 1,66 & 0,76 & .06 \\
emotions & 16-21 children & 257 & 1,69 & 0,75 & \\
& 22 children and above & 152 & 1,58 & 0,83 & \\
\hline
\end{tabular}

${ }^{*} \mathrm{p}<.05$

When table 9 is examined, it has been found out that scores obtained by children included in the research from physical aggression and depressive emotions sub-dimensions are not statistically significant ( $\mathrm{p}>.05)$ according to number of pupils in their class. Children with 15 pupils, 16-21 pupils and more than 21 pupils in their class received 1,54 $\pm 0,70$, $1,69 \pm 0,83$, and $1,51 \pm 0,82$ points on average respectively from relational aggression sub- 
Bilgisayar ve Ë̆itim

Araştırmaları Dergisi

www.joucer.com

www.dergipark.ulakbim.gov.tr/jcer
Journal of Computer and

Education Research

www.joucer.com

www.dergipark.ulakbim.gov.tr/jcer

dimension. It has been found out that scores obtained by children included in the research from relational aggression sub-dimension are statistically significant ( $p>.05)$ according to number of pupils in their class. This difference is caused by the children whose class size is between 16 and 21 pupils. These children received higher scores from relational aggression sub-dimension compared to other children. Children included in the research with 15 pupils, 16-21 pupils and more than 21 pupils in their class received 3,89 $\pm 1,01,3,81 \pm 1,02$ and $4,04 \pm 1,04$ points on average respectively from positive social behaviour exposure sub-dimension. It has been found out that scores obtained by children included in the research from positive social behaviour sub-dimension are statistically significant ( $p>.05)$ according to number of pupils in their class. This difference is caused by the children whose class size is between 16 and 21 pupils. These children received lower scores from positive social behaviour sub-dimension compared to other children.

\section{Discussion and Conclusion}

When the frequency of behaviours in physical aggression and relational aggression sub-dimension are examined, it has been concluded that children displayed these behaviours rarely, occasionally, frequently and always, and that they performed the behaviours in positive social behaviour sub-dimension frequently and do not display behaviours under depressive emotions sub-dimensions, meaning that they are not in depressive emotions.

When the genders of preschool children are examined in terms of their social behaviours, it has been concluded that boys showed more physical aggression, emotional aggression and depressive emotions compared to girls, and girls showed more positive social behaviours compared to boys. In their several studies Crick et al. (1997) found out that boys resorted to physical aggression much more than girls. In a study on aggressive behaviour of children, Katsurada and Sugawara (1998) found out that boys showed more aggressive behaviours than girls. It might be thought that the reason for witnessing aggressive behaviour in boys more frequent than girls is related to the fact that such behaviours of boys receive more approval and encouragement from adults compared to 
Bilgisayar ve Ë̆itim

A raştırmaları Dergisi

www.joucer.com

www.dergipark.ulakbim.gov.tr/jcer
Journal of Computer and

Education Research

www.joucer.com

www.dergipark.ulakbim.gov.tr/jcer

girls. Such behaviours are sometimes related to the value given to boy kids, whereas it might also be related to the general behavioural patterns of the family (Kanllkılıçer, 2005).

It has been identified that, as regards number of siblings of preschool children, those with one sibling showed more positive social behaviour and less depressive emotions compared to children with none or two and more siblings. The relation between high number of siblings and social behaviour problems can be attributed to the crowdedness of the family.

On the other hand, another study revealed similar conclusions. Important findings have been obtained on the relation between number of siblings and behavioural problems. Number of siblings factor was found to be related to both internalized and externalised behaviours, which was a different finding form others. This finding can be explained with the fact that when number of children increase, the time allocated by parents to each child decreases (Seven, 2007).

It has been determined that children with mothers graduated from elementary school showed lower positive social behaviours compared to children with mothers graduated from high school and university/post-graduate schools. Study conducted by Baran (1989) concluded that as the education level of mother declined, behavioural problems increased. In a study conducted by Aral et al. (2006) it was concluded that children of university graduate mothers received higher mean scores from cooperation and social relations dimensions (cited by Karaca, Gündüz \& Aral, 2011).

It has been determined that children with fathers graduated from university / postgraduate schools showed lower physically aggressive behaviour compared to children with fathers graduated from elementary or high schools. Accordingly, based on teacher views it can be claimed that as the education status (level) of the parents declines, relational aggressive behaviour of children become less frequent. Another research which supports this position was made by Durmuşoğlu-Saltalı \& Arslan (2011) which concluded that as the 
Bilgisayar ve $\mathrm{E}_{\text {ğitim }}$

Araştırmaları Dergisi

www.joucer.com

www.dergipark.ulakbim.gov.tr/jcer
Journal of Computer and

Education Research

www.joucer.com

www.dergipark.ulakbim.gov.tr/jcer

education level of the father increased, so did the mean scores of emotional skills obtained by children.

As regards the regions of schools where preschool children are enrolled, it has bene found out that children going to schools in Kyrenia and Güzelyurt region show higher relational aggression compared to children going to schools in other regions; that children going to schools in Nicosia region show lower positive social behaviours compared to children going to schools in other regions; and children going to schools in Kyrenia region show lower depressive emotions compared to children going to schools in other regions.

As regards the number of pupils in classes of preschool children, it has bene seen that children in classes with 16-21 pupils have higher relational aggression scores and lower positive social behaviour scores compared to other children. One study conducted by Derman in 2009 on the teacher-related reasons of aggressive behaviours of children showed that teachers are unable to get interested in students in more crowded classes, which supports this research.

\section{Recommendations}

- Education programs must be developed for parents and teachers on aggressive behaviours of preschool student boys and ways to deal with these behaviours.

- Cooperation must be made with parents and the child in order to eliminate the aggressive behaviours and their results, and teacher-parent communication must be ensured.

- Seminars must be organized in parent education and parents and students must be in cooperation.

- Studies must be conducted to steer boys towards positive behaviours through drama methods.

- Parents with single children must support social behaviours of their child by directing them to social environments.

- Studies must be conducted to determine the reasons for such high scores of relational aggression among preschool children. 
Bilgisayar ve Ë̆itim

A raştırmaları Dergisi

www.joucer.com

www.dergipark.ulakbim.gov.tr/jcer
Journal of Computer and

Education Research

www.joucer.com

www.dergipark,ulakbim.gov.tr/jcer

- The reasons of lower positive social behaviours and higher depressive emotions showed by children in Nicosia region must be looked into.

- In-service education must be provided to teachers and parents on social behaviours of preschool children.

- Researches must be conducted on social behaviours of different age groups and solutions must be recommended.

\section{References}

Acar, K. (2013). Futbol Eğitimi Alan Çocuklarda Problem Çözme Becerilerinin ve Fonksiyonel Olmayan Tutumların İncelenmesi. Master Thesis, Selçuk University, Konya.

Arı, M. (2003). Türkiye'de Erken Çocukluk Eğitimi ve Kalitenin Önemi. Ankara: Anı Yayıncılık.

Baran, G. (1989). On Yaş Çocuklarında Davranış Bozuklukları ile Benlik Kavramının Gelişimi Arasındaki ilişki Üzerine Bir Çalışma. Ankara University Graduate School of Natural Sciences, Department of Household Economics, Master Thesis. Ankara.

Crick, N.R., Casas, J.F. \& Mashar, M. (1997). Relational and Overt Aggression Preschool. Developmental Psycholog. 33(4), 579.

Derman. T.M (2009). “Okulöncesi Eğitim Alan 5-6 Yaş Çocuklarında Sınıf İçinde Gözlenen Saldırgan Davranışlar ve Öğretmenden Kaynaklanan Nedenleri”. e-Journal of New World Sciences Academy 4 (3), 892-907.

Durmuşoğlu-Saltali, N. \& Arslan, E. (2011). "An Investigation of Emotional Skills of SixYear-Old Children Attending Nursery School According to Some Variables". Educational Research and Reviews Vol. 6 (7), 536- 541, July.

Eminoğlu, B. (2007). Dört-Beş Yaş Çocuklarının Sosyal Davranışları ile Ebeveyn Davranışları Arasındaki İlişkinin İncelenmesi. Master Thesis, Gazi University Graduate School of Education Sciences.

Günalp, A. (2007). Farklı Anne Baba Tutumlarının Okul Öncesi Eğitim Çağındaki Çocukların Özgüven Duygusunun Gelişimine Etkisi. Selçuk University Graduate School of Social Sciences, Elementary Education Department, Preschool Teaching Section, Master Thesis, Konya.

Kanlıkılıçer, P. (2005). Okul Öncesi Davranış Sorunları Tarama Ölçeği: Geçerlilik ve Güvenilirlik Çalışması. Marmara University Graduate School of Education Sciences, Department of Preschool Teaching, Master Thesis. İstanbul.

Karasar, N. (2011). Bilimsel Araştırma Yöntemi. Ankara: Nobel Yayın Dağıtım.

Karakuş, A. (2008). Okul Öncesi Sosyal Davranış Ölçeği Öğretmen Formu'nun Güvenirlik ve Geçerlik Çalışması. Master Thesis, Marmara. 
Bilgisayar ve Ĕgitim

Araştırmaları Dergisi

www.joucer.com

www.dergipark.ulakbim.gov.tr/jcer
Journal of Computer and

Education Research

www.joucer.com

www.dergipark.ulakbim.gov.tr/jcer

Karaca, N., Gündüz, A. ve Aral, N., (2011). Okul Öncesi Dönem Çocuklarının Sosyal Davranışının İncelenmesi. Kuramsal Ĕ̆itimbilim Dergisi. 4(2), 65-76

Katsurada, E., Sugawara, A.I. (1998) The Relationship Between Hostile Attributional Bias and Aggressive Behaviour in Preschoolers Early Childhood Research Quarterly. No. 4.

Kılınç, F. (2011). Anne Eğitim Programı İle Anne Çocuk Etkileşim Programının 24-36 Aylık Çocukların Bilişsel Becerilerine Ve Annelerin Çocuk Yetiştirme Davranışlarına Etkisinin İncelenmesi. Selçuk University Graduate School of Social Sciences, Department of Child Development and Household Economics, Section of Child Development and Education, PhD Thesis, Konya.

Oktay, A. (2003). 21.Yüzyıla Girerken Dünyada Yaşanan Değişimler ve Erken Çocukluk Eğitimi. İstanbul: Epsilon Yayınları.

Özkafacı, A. (2012). Annenin Çocuk Yetiştirme Tutumu İle Çocuğun Sosyal Beceri Düzeyi Arasındaki İlişkinin İncelenmesi. İstanbul Ar-El University Graduate School of Social Sciences, Department of Psychology, Master Thesis İstanbul.

Seven, S. (2007). Ailesel Faktörlerin Altı Yaş Çocuklarının Sosyal Davranış Problemlerine Etkisi, Kuram ve Uygulamada Ĕ̈itim Yönetimi Dergisi. 13(3), 477-499.

\section{Citation Information}

Amca, D. \& Kıvanç Öztuğ, E. (2016). Examination of the social behavior of 4 age old preschool children according to teacher views. Journal of Computer and Education Research, 4 (7), 82-102. 